\title{
Difference in Risks of Allergic Reaction to Sulfonamide Drugs Based on Chemical Structure
}

\author{
B Marianne Verdel, Patrick C Souverein, Antoine CG Egberts, and Hubert GM Leufkens
}

\begin{abstract}
BACKGROUND: The chemical structure of sulfonamide antibiotics and sulfonamide nonantibiotics can affect the potential for adverse reactions.

OBJECTIVE: To assess whether differences in chemical structure of the various sulfonamide drugs influence the risk of allergic events.

METHODS: A case-control study was conducted among patients with diabetes mellitus (DM) using data from the General Practice Research Database. Cases were defined as patients with a diagnosis of hypersensitivity or allergic reaction. The date of the last event was the index date. Controls were matched on practice, type of DM, and index date. Current use of sulfonamides was defined as use in a 14 day time window before the index date. Sulfonamides were classified according to the presence/absence of an N1 substituent $\left(\mathrm{N}^{+}{ }^{+-}\right)$and/or an arylamine $\left(\mathrm{N}^{+}{ }^{+-}\right)$. Conditional logistic regression was used to estimate strength of association and expressed as odds ratios and $95 \%$ confidence intervals.
\end{abstract}

RESULTS: Overall, current use of $\mathrm{N} 1^{+} \mathrm{N}^{+}$sulfonamide drugs was associated with the outcome (adjusted $\mathrm{OR} 3.71 ; 95 \% \mathrm{Cl} 1.40$ to 9.81). Current use of $\mathrm{N1}^{+} \mathrm{N}^{-}$and $\mathrm{N1}^{-} \mathrm{N}^{-}$sulfonamide drugs was also associated with the occurrence of allergic reactions, although not as strongly: adjusted OR 2.48 (95\% Cl 2.12 to 2.89$)$ and 2.07 (95\% Cl 1.74 to 2.46$)$, respectively. Sex and age seemed to be effect modifiers. There was no clear evidence for effect modification by immune disease state.

CONCLUSIONS: Although we did not identify major differences between the groups, we believe that this approach is an innovative manner to examine adverse drug reactions by using chemical structure instead of therapeutic drug classes to classify exposure.

KEY WORDS: allergic reactions, chemical structure, diabetes mellitus, sulfonamide drugs.

Ann Pharmacother 2006;40:1040-6.

Published Online, 30 May 2006, www.theannals.com, DOI 10.1345/aph.1G642

$S_{0}$ ulfonamide antibiotics and sulfonamide nonantibiotics, such as sulfonylureas and thiazide diuretics, are well known to have the capacity to cause hypersensitivity reactions. ${ }^{1-3}$ Although in some patients, possible cross-reactivity has occurred between a sulfonamide antibiotic and a sulfonamide nonantibiotic, ${ }^{4-8}$ the issue of cross-reactivity remains controversial. Available evidence suggests that sulfonamide antibiotics probably do not cross-react with sulfonamide nonantibiotics. ${ }^{9-13}$ Both sulfonamide antibiotics and nonantibiotics are compounds with a sulfon-

Author information provided at the end of the text. amide moiety $\left(\mathrm{SO}_{2} \mathrm{NH}_{2}\right)$. Not withstanding this same chemical structure, the group is very heterogeneous with respect to three-dimensional structures.

Sulfonamide antibiotic-induced hypersensitivity reactions involve a complex combination of metabolic and immunological events. Sulfonamide antibiotics are derivatives of sulfanilamide (Figure 1a). They contain an aromatic amine group at the $\mathrm{N} 4$ position and a substituent at the $\mathrm{N} 1$ position. The aromatic amine moiety is considered to be the trigger for serious drug reactions, due to the formation of reactive hydroxylamine intermediates and the subsequent haptenation product. ${ }^{14}$ Type 1 allergic reactions to sulfonamide antibiotics appear to be directed by the sub- 
stituents at the N1 position. The attachment of a 5- or 6member aromatic heterocyclic ring with at least 1 nitrogen to the sulfonamido-N1 and the presence of a single methyl group ( $\beta$-position) on the second carbon atom are important allergenic determinants (Figure 1b), ${ }^{9,11,12}$

Sulfonamide nonantibiotics lack both the aromatic amine moiety and an N1 substituent with a 5- or 6-member aromatic heterocyclic ring (Figure 2). On a chemical basis, it has been considered unlikely that the risk of a hypersensitivity reaction or allergic event after use of a sulfonamide antibiotic and a nonantibiotic is the same. On the basis of the chemical structure, Johnson et al. ${ }^{10}$ divided sulfonamides into 3 groups: arylamines (a sulfonamide moiety connected to a benzene ring with an unsubstituted amine moiety at the $\mathrm{N} 4$ position, $\mathrm{N}^{+}$), nonarylamines (a sulfonamide moiety connected to a benzene ring or other cyclic structure without the amine moiety at the $\mathrm{N} 4$ position, $\mathrm{N}^{-}$), and a group in which the sulfonamide moiety was not directly connected to the benzene ring. However, in the nonarylamines group, they made no distinction between sulfonamides that lacked a 5- or 6-member aromatic heterocyclic ring $\left(\mathrm{N1}^{-}\right)$and sulfonamides that had a different type of substituent at the $\mathrm{N} 1$ position $\left(\mathrm{N} 1^{+}\right)$.

In this study we classified sulfonamide drugs according to the absence or presence of N1 substituents and the absence or presence of an arylamine. The objective of this study was to determine whether the presence of N1 substituents and the aromatic amine moiety in sulfonamide drugs influence the occurrence of hypersensitivity reactions and allergic events. We chose to conduct a study with patients with diabetes mellitus (DM), as the frequency of use of sulfonamide drugs is relatively high within such patients.

\section{Methods}

\section{SETTING}

The data for this study were obtained from the General Practice Research Database (GPRD), which contains the computerized medical

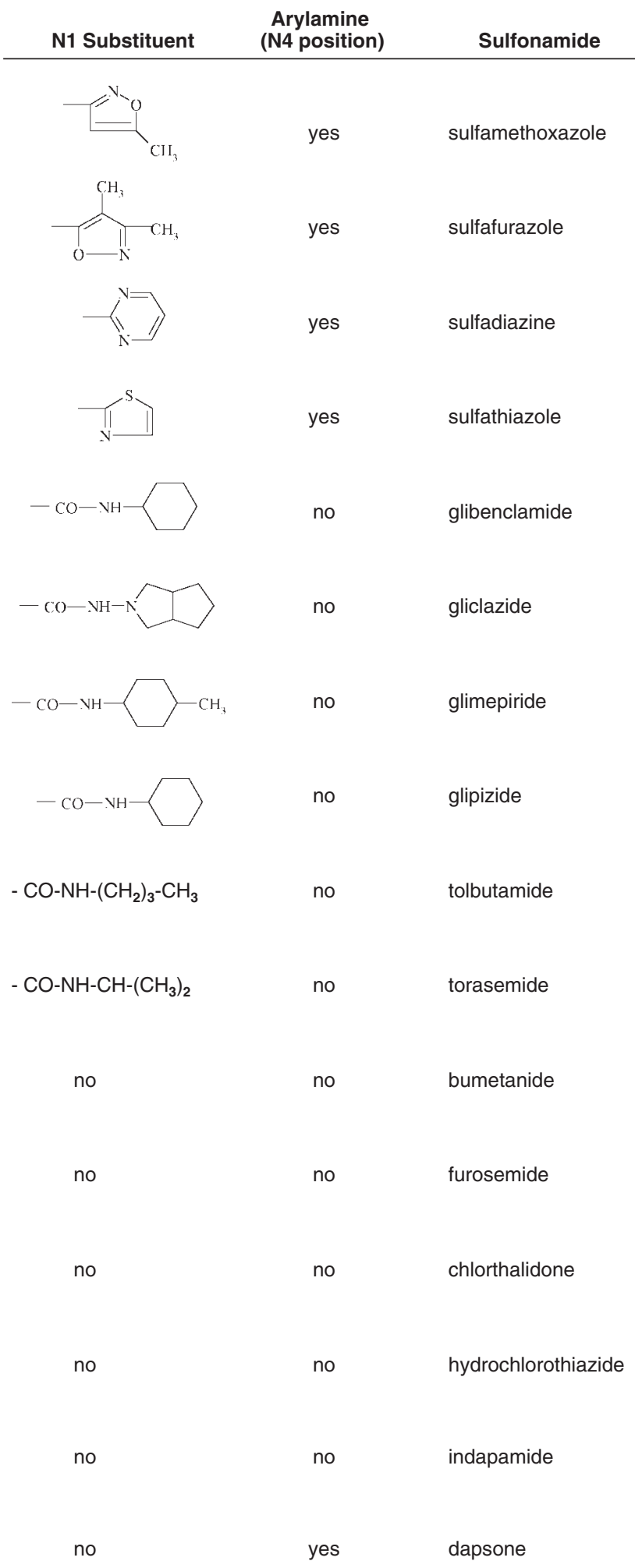

Figure 2. Examples of sulfonamide drugs classified by N1 substituents and N4 position.

Figure 1. $A$ = sulfanilamide; $B$ = sulfamethoxazole. 
records of about 650 general practices, comprising over 35 million patient-years of data collected from almost 9 million patients. ${ }^{15}$ The data accrued in the GPRD include demographic information about the patient, prescription details, clinical events, preventive care provided, referrals to specialist care, and hospital admissions and their major outcomes. ${ }^{16}$ Clinical data are stored and retrieved by means of Oxford Medical Information Systems (OXMIS) and Read codes for diseases or causes of morbidity and mortality that are cross-referenced to the International Classification of Diseases (ICD -9).

Each entry into GPRD is internally validated by crosschecking within the practice and by comparisons with external statistics. Only data from practices that pass this quality control are compiled to form the GPRD database. Several independent validation studies have shown that the GPRD database has a high level of completeness and validity. ${ }^{16,17}$ The GPRD is owned by the UK Department of Health and managed by the Medicines Control Agency. ${ }^{15}$

\section{STUDY BASE}

From the GPRD, we identified all patients with either a diagnosis of diabetes (ICD -9 code 250) or a prescription for a drug indicated for the treatment of DM (ie, insulin and/or oral antidiabetic drugs) in the period from 1987 to 2001. Patients were followed from their first diagnosis of DM (after practice up-to-standard) or the start of the data collection of the practice (when a patient had a first diagnosis of DM prior to the practice's up-to-standard date) to the end of the study period.

\section{CASES AND CONTROLS}

Within the study base, a nested case-control study was conducted. Cases were defined as patients with at least one diagnosis of hypersensitivity or allergic reaction (eg, anaphylaxis, urticaria, angioedema, allergic rash, allergic dermatitis, and toxic epidermal necrolysis; for selected OXMIS/Read codes, see Appendix I) during the study period. The date of the last recorded event of the outcome event was the index date, because we also wanted to study the effect of prior hypersensitivity or allergic events. For each case, up to 3 controls were sampled and matched on type of DM, general practice, and index date. Potential controls were patients from the study base who did not have one of such outcomes during the study period. We made a distinction between patients using insulin only (type 1) and those using oral antidiabetic agents only or who had a diagnosis of DM without medication (type 2). Both cases and controls were eligible for inclusion if they had a minimum period of 365 days of history in the GPRD prior to the index date.

\section{EXPOSURE ASSESSMENT}

Sulfonamide drugs were classified by the presence of an N1 substituent and an aromatic amine moiety (Appendix II). The abbreviations $\mathrm{N}^{+}$and $\mathrm{N1}^{-}$indicate the presence or absence, respectively, of a substituent at the $\mathrm{N} 1$ position; $\mathrm{N}^{+}$and $\mathrm{N}^{-}$indicate the presence or absence, respectively, of an arylamine. For each patient, we identified all prescriptions for sulfonamide drugs in the year before the index date.

Drug exposure was categorized according to the timing of use in relation to the index date. Patients were defined as current users when they had received either a prescription in a 14 day time window prior to the index date or the theoretical end date of an earlier prescription was within or after this time window. If the end date of the last prescription was from 14 to 365 days before the index date, drug use was defined as past. No use was defined as no prescription of a sulfonamide within 1 year before the index date.

\section{DATA ANALYSIS}

The strength of the association between sulfonamide drug use and hypersensitivity and allergic reactions was ascertained by conditional logistic regression analysis and expressed as crude and adjusted OR with $95 \%$ CI. The model included current and past use of sulfonamide agents. Covariates were included in the multivariate model if they were either significantly $(\mathrm{p}<0.05)$ associated with the outcome in a univariate analysis or induced a $10 \%$ change of the crude OR of the exposure variable.

It has been reported that a history of previous adverse drug reactions is an important risk factor for adverse drug reactions. ${ }^{11,18}$ Female sex and age are also risk factors for such events. ${ }^{13,18-21}$ Sex, age, a history of allergic events, and a history or presence of an immune disease were evaluated as effect modifiers to assess differential risk. Immune diseases included asthma, rhinitis, eczema, and rheumatoid arthritis. Patients with DM types 1 and 2 (with or without oral antidiabetic drugs) were analyzed as subgroups.

\section{Results}

The study base comprised 141164 patients with either a diagnosis of DM or a prescription for a drug indicated for the treatment of DM. We identified 3362 (2.4\%) cases with a record of a hypersensitivity reaction or allergic event. Urticaria was the most frequent allergic-like event ( $\mathrm{n}=1536,45.7 \%)$, followed by allergic rash $(\mathrm{n}=961$, $28.6 \%)$ and allergic reactions $(\mathrm{n}=432,12.8 \%)$. Thirteen cases $(0.4 \%)$ experienced anaphylactic shock; angioedema occurred in 120 patients $(3.6 \%)$.

The characteristics of the study population are shown in Table 1 . The mean age \pm SD was $59 \pm 18$ years (control group $64 \pm 18$ ). Female gender, age 65 years or less, and a history or presence of an immune disease were associated with the occurrence of hypersensitivity reactions and allergic events.

The association between the use of sulfonamide drugs and the risk of hypersensitivity reactions and allergic events is shown in Table 2. The prevalence of current sulfonamide drug use was higher among cases (40.2\%) than among controls (28.0\%), yielding a crude OR of 2.16 (95\% CI 1.92 to 2.43). This association persisted after adjusting for sex, age, and immune disease state (OR 2.36, $95 \%$ CI 2.08 to 2.69 ).

Stratification according to the presence or absence of an N1 substituent or an arylamine showed that the current use of sulfonamide drugs with $\mathrm{N}^{+} \mathrm{N}^{+}$was most clearly associated with the occurrence of hypersensitivity and allergic reactions (adjusted OR 3.71; 95\% CI 1.40 to 9.81). Current use of $\mathrm{N}^{+} \mathrm{N}^{-}$and $\mathrm{N1}^{-} \mathrm{N}^{-}$sulfonamide drugs was also associated with the occurrence of allergic reactions, although the association was not as strong as that with $\mathrm{N1}^{+}$ $\mathrm{N} 4^{+}$sulfonamide drugs (Table 2). Current use of more than one sulfonamide at the time yielded an OR of $3.05(95 \%$ CI 2.44 to 3.82). Sex, age, and immune disease state were evaluated as effect modifiers. We also stratified on the 
presence or absence of N1 substituents and the presence or absence of an arylamine in sulfonamide drugs. The association between current use of a sulfonamide drug and allergic events was stronger among males compared with females, as was age greater than 65 years (Table 3 ). We found no difference in patients with or without an immune disease state or a history of an allergic event. Among current users of a sulfonamide, the risk seemed most pronounced among patients with DM using oral antidiabetic drugs (Table 3 ).

\begin{tabular}{|c|c|c|c|c|c|}
\hline \multirow[b]{2}{*}{ Characteristics } & \multicolumn{2}{|c|}{$\begin{array}{c}\text { Cases } \\
(n=3362)\end{array}$} & \multicolumn{2}{|c|}{$\begin{array}{c}\text { Controls } \\
(n=10041)\end{array}$} & \multirow[b]{2}{*}{ Crude OR $(95 \% \mathrm{Cl})$} \\
\hline & $\mathbf{n}$ & $\%$ & $\mathbf{n}$ & $\%$ & \\
\hline \multicolumn{6}{|l|}{ Sex } \\
\hline female & 2024 & 60.2 & 4679 & 46.6 & 1.75 (1.61 to 1.89$)$ \\
\hline male & 1338 & 39.8 & 5362 & 53.4 & 1.00 (reference) \\
\hline \multicolumn{6}{|l|}{ Age $(y)$} \\
\hline$\leq 65$ & 1955 & 58.1 & 4663 & 46.4 & $1.69(1.55$ to 1.83$)$ \\
\hline$>65$ & 1407 & 41.9 & 5378 & 53.6 & 1.00 (reference) \\
\hline \multicolumn{6}{|l|}{ Type of diabetes } \\
\hline 1 & 700 & 20.8 & 2090 & 20.8 & NA \\
\hline $\begin{array}{l}2 \text { (use of oral } \\
\text { antidiabetic drugs) }\end{array}$ & 1817 & 54.0 & 5451 & 54.3 & NA \\
\hline 2 (diagnosis only) & 845 & 25.1 & 2500 & 24.9 & NA \\
\hline $\begin{array}{l}\text { Prior hypersensitivity } \\
\text { or allergic event }\end{array}$ & 673 & 20.0 & 0 & 0.0 & NA \\
\hline Immune disease state ${ }^{a}$ & 868 & 25.8 & 790 & 7.9 & 4.15 (3.72 to 4.64$)$ \\
\hline \multicolumn{6}{|l|}{$\begin{array}{l}\text { Comorbidity in the year } \\
\text { before index date }\end{array}$} \\
\hline amyloid disease & 12 & 0.4 & 22 & 0.2 & $1.64(0.81$ to 3.31$)$ \\
\hline asthma & 192 & 5.7 & 234 & 2.3 & $2.57(2.11$ to 3.13$)$ \\
\hline Behçet syndrome & 6 & 0.2 & 7 & 0.1 & 2.57 (0.86 to 7.65$)$ \\
\hline colitis & 10 & 0.3 & 14 & 0.1 & 2.14 (0.95 to 4.82$)$ \\
\hline eczema & 208 & 6.2 & 191 & 1.9 & $3.38(2.76$ to 4.13$)$ \\
\hline erythromelalgia & 1 & 0.0 & 6 & 0.1 & $0.50(0.06$ to 4.15$)$ \\
\hline rheumatoid arthritis & 18 & 0.5 & 25 & 0.2 & 2.14 (1.17 to 3.92$)$ \\
\hline rhinitis & 88 & 2.6 & 115 & 1.1 & 2.35 (1.76 to 3.12$)$ \\
\hline scleroderma & 3 & 0.1 & 1 & 0.0 & 9.00 (0.94 to 86.52$)$ \\
\hline spondyloarthritis & 43 & 1.3 & 65 & 0.6 & $1.97(1.34$ to 2.90$)$ \\
\hline vasculitis & 6 & 0.2 & 11 & 0.1 & 1.64 (0.61 to 4.43$)$ \\
\hline \multicolumn{6}{|c|}{$\begin{array}{l}\text { NA = not applicable. } \\
\text { aAsthma/drugs used for asthma, rhinitis, eczema, colitis, rheumatoid arthritis, amy- } \\
\text { loid disease, Behçet syndrome, scleroderma, erythromelalgia, vasculitis, spondy- } \\
\text { loarthritis. }\end{array}$} \\
\hline
\end{tabular}

\section{Discussion}

We found that the risk of hypersensitivity or an allergic reaction after use of a sulfonamide drug was approximately 2 times greater than the risk for subjects who did not use any sulfonamide. Stratifying according to these substituents at the N1 and N4 positions showed that there was a differential risk between the groups of sulfonamides, although the difference was not statistically significant. The increase in risk was most pronounced for sulfonamide drugs with an N1 substituent with a 5or 6-member aromatic heterocyclic ring and an arylamine (predominantly sulfonamide antibiotics). This finding is in agreement with results of studies that consider the N1 and N4 substituents of the sulfonamide antibiotics powerful predictors of immunologic response., ${ }^{911,20}$

Although $\mathrm{N}^{+} \mathrm{N}^{-}$and $\mathrm{N1}^{-} \mathrm{N}^{-}$sulfonamide agents (primarily sulfonylureas and diuretics, respectively) lack both the N1 substituent with a 5- or 6-member aromatic heterocyclic ring and an arylamine, both groups were associated with an increased risk of hypersensitivity and allergic reactions. Both $\mathrm{N}^{+}$ N4- and N1- N4- $^{-}$sulfonamides are most often used chronically. Still, we found a twofold increase of the risk of an allergic event associated with current use of these agents. Current use of more than one sulfonamide increased

\begin{tabular}{|c|c|c|c|c|c|c|}
\hline \multirow{2}{*}{$\begin{array}{l}\text { Sulfonamide } \\
\text { Drug Use }\end{array}$} & \multicolumn{2}{|c|}{$\begin{array}{c}\text { Cases } \\
(\mathrm{n}=3362)\end{array}$} & \multicolumn{2}{|c|}{$\begin{array}{c}\text { Controls } \\
(n=10041)\end{array}$} & \multirow{2}{*}{$\begin{array}{l}\text { Crude OR } \\
(95 \% \mathrm{Cl})\end{array}$} & \multirow{2}{*}{$\begin{array}{l}\text { Adjusted OR } \\
\left(^{(95 \% \mathrm{Cl})^{\mathrm{a}}}\right.\end{array}$} \\
\hline & $\mathrm{n}$ & $\%$ & $\mathrm{n}$ & $\%$ & & \\
\hline None & 1166 & 34.7 & 4026 & 40.1 & 1.00 (reference) & 1.00 (reference) \\
\hline \multicolumn{7}{|l|}{ Current } \\
\hline any & 1353 & 40.2 & 2815 & 28.0 & 2.16 (1.91 to 2.43$)$ & 2.36 (2.08 to 2.69 ) \\
\hline $\mathrm{N} 1^{+} \mathrm{N} 4^{+}$only & 10 & 0.3 & 10 & 0.1 & 3.90 (1.60 to 9.48$)$ & 3.71 ( 1.40 to 9.81$)$ \\
\hline $\mathrm{N} 1^{+} \mathrm{N}^{-}$- only & 845 & 25.1 & 1856 & 18.5 & 2.24 (1.94 to 2.59 ) & 2.48 (2.12 to 2.89 ) \\
\hline $\mathrm{N} 1^{-} \mathrm{N}^{-}$- only & 302 & 9.0 & 602 & 6.0 & 1.91 (1.63 to 2.24 ) & 2.07 (1.74 to 2.46$)$ \\
\hline $\mathrm{N}_{1}^{-} \mathrm{N} 4^{+}$only & 0 & 0.0 & 0 & 0.0 & NA & NA \\
\hline$>1$ drug & 196 & 5.8 & 347 & 3.5 & 2.74 (2.22 to 3.38$)$ & 3.05 (2.44 to 3.82$)$ \\
\hline $\begin{array}{l}\mathrm{N}^{+}{ }^{+} 4^{+}=\text {substituent at } \mathrm{N} 1 \mathrm{p} \\
\mathrm{N} 1^{-} \mathrm{N}^{-}=\text {no substituent at } \mathrm{N} \\
=\text { not applicable. } \\
{ }^{\text {aAdjusted for }} \text {. }\end{array}$ & $\begin{array}{l}\text { arylam } \\
\text { n, no }\end{array}$ & te. & zide & ics & $\begin{array}{l}\text { substituent at } \mathrm{N} 1 \\
=\text { no substituent at }\end{array}$ & $\begin{array}{l}\text { no arylamine (eg, } \\
\text { ion, arylamine (eg, }\end{array}$ \\
\hline
\end{tabular}


the risk of a hypersensitivity or allergic reaction 3 times compared with the risk in nonusers.

Risk estimates did not differ between patients with (a history of) immune diseases or a previous allergic event. However, stratification according to age and sex did reveal differences in risk. It has been suggested that female sex is a risk factor for the occurrence of adverse drug reactions. ${ }^{18,19,21}$ However, our findings do not support those data. We did identify an increased risk of an allergic reaction in patients older than 65 years with DM. This result is consistent with those of studies suggesting that adverse reactions are more common in elderly patients. ${ }^{22,23}$

In patients with type $2 \mathrm{DM}$ who are using oral antidiabetic drugs, the risk of a hypersensitivity reaction associated with current use of a sulfonamide agent was higher than in patients with type $1 \mathrm{DM}$ and in those with a diagnosis DM who were not receiving drug therapy. The number of patients using $\mathrm{N}^{+}{ }^{+} 4^{+}$sulfonamide drugs was small, but the association was also present in the much larger group of $\mathrm{N1}^{-} \mathrm{N}^{-}$sulfonamide drug users.

There are potential methodologic limitations to our study. In our case definition, we selected codes for hypersensitivity and allergic reactions and excluded codes that suggested non-unique causes. Therefore, it is possible that the lists of codes in Appendix I omitted codes for hypersensitivity reactions and allergic events. Misclassification with respect to the recording of diagnosis of hypersensitivity reactions and allergic events cannot be excluded, but it seems unlikely that misclassification was differential between cases and controls.

The timing of the outcome events was an important factor. The potential immunologic reaction related to sulfonamide antibiotics usually develops within 1-3 days of initial medication; the hypersensitivity reaction requiring the presence of an arylamine has a delayed onset, usually within 7-14 days. ${ }^{910}$ Hypersensitivity reactions caused by some sulfonamide drugs $\left(\mathrm{N}^{+}{ }^{+} 4^{-}\right)$usually occur in the first 6-8 weeks of therapy. Because most of the outcome events are mild dermatologic endpoints, it is possible that those events were not diagnosed or not reported directly after the onset of the events.

We did compute the OR and 95\% CI for risk of a hypersensitivity reaction or allergic event within a 30 day time window prior to the index date. The ORs and 95\% CIs did not differ substantially (data not shown). Furthermore, as dermatologic events are known adverse effects of sulfonamide drugs, we cannot exclude the possibility that diagnostic suspicion bias accounts for part of the observed outcome events. There could also have been other variables that we could not control; therefore, residual confounding is possible.

This study was conducted among patients with DM because the use of sulfonamides is usually relatively high in such patients. To our knowledge, patients with DM are not at greater risk for hypersensitivity reactions after use of sulfonamide drugs than are patients who are not diabetic.

\begin{tabular}{|c|c|c|c|c|}
\hline \multicolumn{5}{|c|}{$\begin{array}{l}\text { Table 3. Stratified Variables Associated with Current Use of Sulfonamide Drugs and Risk of } \\
\text { Hypersensitivity Reactions and Allergic Events }\end{array}$} \\
\hline Exposure & $\begin{array}{l}\text { Any } \\
\text { Sulfonamide Drug } \\
\text { Adjusted OR } \\
(95 \% \mathrm{Cl})^{\mathrm{a}}\end{array}$ & $\begin{array}{l}\mathrm{N1}^{+} \mathrm{N}^{+} \\
\text {Adjusted OR } \\
\text { (95\% Cl) }\end{array}$ & $\begin{array}{l}\mathrm{N1}^{+} \mathrm{N}^{-} \\
\text {Adjusted OR } \\
\text { (95\% Cl) }\end{array}$ & $\begin{array}{l}\mathrm{N1}^{-} \mathrm{N}^{-} \\
\text {Adjusted OR } \\
(95 \% \mathrm{Cl})\end{array}$ \\
\hline \multicolumn{5}{|l|}{ Sex } \\
\hline female & $2.10(1.79 \text { to } 2.45)^{\mathrm{b}}$ & 4.61 (1.34 to 15.86$)$ & 2.26 (1.87 to 2.72$)$ & $1.72(1.39 \text { to } 2.15)^{b}$ \\
\hline male & 2.74 (2.31 to 3.24$)$ & $2.32(0.42$ to 12.96$)$ & 2.75 (2.26 to 3.34$)$ & 2.67 (2.05 to 3.49$)$ \\
\hline \multicolumn{5}{|l|}{ Age (y) } \\
\hline$\leq 65$ & $1.79(1.53 \text { to } 2.10)^{b}$ & 3.69 (1.18 to 11.57$)$ & $1.91(1.59 \text { to } 2.30)^{\mathbf{b}}$ & $1.52(1.16 \text { to } 1.99)^{\mathrm{b}}$ \\
\hline$>65$ & $2.53(2.12$ to 3.02$)$ & $4.19(0.73$ to 24.04$)$ & 2.77 (2.26 to 3.39$)$ & $2.16(1.72$ to 2.70$)$ \\
\hline \multicolumn{5}{|c|}{ Immune disease state } \\
\hline yes & 2.65 (2.05 to 3.43 ) & $3.37(0.22$ to 51.96$)$ & 2.64 (1.96 to 3.56$)$ & 2.73 (1.86 to 4.00$)$ \\
\hline no & 2.31 (2.02 to 2.65$)$ & $3.87(1.37$ to 10.89$)$ & 2.44 (2.07 to 2.86$)$ & 1.95 (1.61 to 2.36$)$ \\
\hline \multicolumn{5}{|l|}{ Type of diabetes } \\
\hline 1 & 1.86 (1.29 to 2.67$)$ & 2.58 (0.61 to 10.95$)$ & NA & $1.86(1.27$ to 2.71$)$ \\
\hline 2 & 2.80 (2.28 to 3.43$)$ & 7.25 (1.56 to 33.63$)$ & 2.67 (2.17 to 3.28$)$ & 3.04 (2.25 to 4.12$)$ \\
\hline diagnosis only & $1.48(1.13$ to 1.93$)$ & $2.92(0.26$ to 32.85$)$ & 0.65 (0.08 to 5.59$)$ & $1.48(1.13$ to 1.93$)$ \\
\hline \multicolumn{5}{|c|}{ Previous allergic event } \\
\hline yes & 2.75 (2.03 to 3.72$)$ & $4.36(0.26$ to 73.92$)$ & 2.69 (1.89 to 3.83$)$ & 2.85 (1.91 to 4.25$)$ \\
\hline no & 2.30 (1.99 to 2.65$)$ & $3.67(1.31$ to 10.32$)$ & 2.45 (2.06 to 2.90$)$ & $1.93(1.59$ to 2.34$)$ \\
\hline \multicolumn{5}{|c|}{$\begin{array}{l}\mathrm{N} 1^{+} \mathrm{N} 4^{+}=\text {substituent at } \mathrm{N} 1 \text { position, arylamine (eg, sulfonamide antibiotics); } \mathrm{N} 1^{+} \mathrm{N} 4^{-}=\text {substituent at } \mathrm{N} 1 \text { position, no arylamine (eg, sulfony- } \\
\text { lureas); } \mathrm{N}^{-} \mathrm{N} 4^{-}=\text {no substituent at } \mathrm{N} 1 \text { position, no arylamine (eg, thiazide diuretics); } \mathrm{NA}=\text { not applicable. } \\
\text { aAdjusted for sex, age, and immune disease state. } \\
\text { bStatistically significant difference }(\mathrm{p}<0.05) \text {. }\end{array}$} \\
\hline
\end{tabular}


Previous reports that mention the risk of hypersensitivity reactions after use of sulfonamides do not categorize these agents according to their substituents. Recategorizing these medications in the defined chemical structure categories could be helpful to obtain a new perspective on the problem of "sulfa" allergy and/or cross-reactivity between drugs with a sulfonamide moiety.

\section{Conclusions}

In this study we used an innovative manner to examine adverse drug reactions by using chemical structures instead of a traditional pharmacology-based classification to assess exposure. Although our results did not show an obvious difference in risk of a hypersensitivity or allergic reaction after using a sulfonamide drug classified according to substituents at the $\mathrm{N} 1$ and $\mathrm{N} 4$ positions, we believe that structure-activity relationships related to drug exposure will play a major role in the future.

Further research is needed to establish whether a possible association exists between the presence or absence of substituents of sulfonamide drugs and the occurrence of hypersensitivity reactions.

B Marianne Verdel PharmD, PhD Student, Division of Pharmacoepidemiology and Pharmacotherapy, Utrecht Institute for Pharmaceutical Sciences (UIPS), Faculty of Science, Utrecht University, Utrecht, Netherlands

Patrick C Souverein PhD, Epidemiologist, Division of Pharmacoepidemiology and Pharmacotherapy, UIPS

Antoine CG Egberts PhD, Clinical Pharmacist, Hospital Pharmacy Midden-Brabant, TweeSteden Hospital and St. Elisabeth Hospital, Tilburg, Netherlands; Professor of Clinical Pharmacoepidemiology, Division of Pharmacoepidemiology and Pharmacotherapy, UIPS Hubert GM Leufkens PhD, Professor of Pharmacoepidemiology, Division of Pharmacoepidemiology and Pharmacotherapy, UIPS

Reprints: Dr. Verdel, Division of Pharmacoepidemiology and Pharmacotherapy, Utrecht Institute for Pharmaceutical Sciences, Utrecht University, PO Box 80082, 3508 TB Utrecht, Netherlands, fax 3130253 9166, b.m.verdel@pharm.uu.nl

\section{References}

1. Cribb AE, Lee BL, Trepanier LA, Spielberg SP. Adverse reactions to sulphonamide and sulphonamide-trimethoprim antimicrobials: clinical syndromes and pathogenesis. Adverse Drug React Toxicol Rev 1996;15:9-50.

2. Krans HMJ. Insulin, glucagon and oral hypoglycemic drugs. In: Dukes MNG, Aronson JK, eds. Meyler's side effects of drugs. 14th ed. Amsterdam: Elsevier, 2000: 1501-19.

3. McInnes GT. Diuretics. In: Dukes MNG, Aronson JK, eds. Meyler's side effects of drugs. 14th ed. Amsterdam: Elsevier, 2000:656-82.

4. Glasser DL, Burroughs SH. Valdecoxib-induced toxic epidermal necrolysis in a patient allergic to sulfa drugs. Pharmacotherapy 2003;23:551-3.

5. Wiholm BE. Identification of sulfonamide-like adverse drug reactions to celecoxib in the World Health Organization database. Curr Med Res Opin 2001;17:210-6.

6. Ernst EJ, Egge JA. Celecoxib-induced erythema multiforme with glyburide cross-reactivity. Pharmacotherapy 2002;22:637-40.
7. Bukhalo M, Zeitouni NC, Cheney RT. Leukocytoclastic vasculitis induced by use of glyburide: a case of possible cross-reaction of a sulfonamide and a sulfonylurea. Cutis 2003;71:235-8.

8. Hansbrough JR, Wedner HJ, Chaplin DD. Anaphylaxis to intravenous furosemide. J Allergy Clin Immunol 1987;80:538-41. DOI 10.1016/0091-6749(87)90004-2

9. Brackett CC, Singh H, Block JH. Likelihood and mechanisms of crossallergenicity between sulfonamide antibiotics and other drugs containing a sulfonamide functional group. Pharmacotherapy 2004;24:856-70.

10. Johnson KK, Green DL, Rife JP, Limon L. Sulfonamide cross-reactivity: fact or fiction? Ann Pharmacother 2005;39:290-301. Epub 2005 Jan 11. DOI 10.1345/aph.1E350

\begin{tabular}{|c|c|c|}
\hline \multicolumn{3}{|c|}{$\begin{array}{l}\text { Appendix I. Diagnoses Included in the Definitions of } \\
\text { Hypersensitivity Reactions and Allergic Events }\end{array}$} \\
\hline Definition & OXMIS Codes & Read Codes \\
\hline Urticaria (NOS) & 7089 & M28..00-M28z.00 \\
\hline Urticaria, allergic & 7089AL & \\
\hline Urticaria, cholinergic & $7080 \mathrm{C}$ & \\
\hline Dermatosis, allergic & $7089 D$ & \\
\hline Urticaria, giant & $7080 G$ & \\
\hline Angioneurotic edema & 7080AN & SN51.00 \\
\hline Angioedema & $7080 \mathrm{AO}$ & \\
\hline Edema, allergic & $7080 \mathrm{AL}$ & \\
\hline Rash, allergic & 7089AR & \\
\hline Dermatitis, allergic & $6929 \mathrm{E}$ & \\
\hline Reaction, allergic & $6929 G$ & \\
\hline Skin allergy & 6929EA & \\
\hline Skin allergic reaction & 6929ER & \\
\hline Erythema multiforme & 6951 & M151.00 \\
\hline Stevens-Johnson syndrome & $6951 \mathrm{MJ}$ & M151700 \\
\hline Toxic epidermal necrolysis & 6951NE & M151.12-M151800 \\
\hline Shock (circulatory) & 7829 & \\
\hline Anaphylactic shock & 9994 & SN50.00 \\
\hline Hypersensitivity (NOS) & & SN53.11 \\
\hline Hypersensitivity angiitis & & G752.00 \\
\hline Urticaria, papular & 6982AR & \\
\hline Laryngeal spasm & $508 \mathrm{~T}$ & $\mathrm{H} 1 \mathrm{y} 7400$ \\
\hline
\end{tabular}

Appendix II. Classification of Sulfonamide Drugs According to the Presence and/or Absence of an N1 Substituent and an Arylamine (N4)

\begin{tabular}{|c|c|c|}
\hline $\begin{array}{c}\text { N1 } \\
\text { Substituent }\end{array}$ & $\begin{array}{l}\text { Arylamine } \\
\text { (N4) }\end{array}$ & Sulfonamides \\
\hline+ & + & $\begin{array}{l}\text { amprenavir, calcium sulfaloxate, succinyl sulfathiazole, } \\
\text { sulfacetamide, sulfadiazine, sulfadimethoxine, sulfa- } \\
\text { dimidine, sulfafurazole, sulfaguanidine, sulfamethizole, } \\
\text { sulfamethoxazole, sulfamethoxypuridazine, sulfame- } \\
\text { topyrazine, sulfamezathine, sulfamoxole, sulfaphena- } \\
\text { zole, sulfapyridine, sulfasuxidine, sulfathiazole }\end{array}$ \\
\hline+ & - & $\begin{array}{l}\text { acetohexamide, almotriptan, chlorpropamide, gliben- } \\
\text { clamide, glibornuride, gliclazide, glimepiride, glipizide, } \\
\text { gliquidone, glymidine, probenecid, sotalol, tolazamide, } \\
\text { tolbutamide, torasemide }\end{array}$ \\
\hline- & - & $\begin{array}{l}\text { acetazolamide, bendrofluazide, bumetanide, celecoxib, } \\
\text { chlorothiazide, chlorthalidone, clopamide, clorexolone, } \\
\text { cyclopenthiazide, diazoxide, ethiazide, famotidine, } \\
\text { furosemide, hydrochlorothiazide, piretanide, sarfruse- } \\
\text { mide, hydroflumethiazide, indapamide, methyclothia- } \\
\text { zide, metolazone, naratriptan, polythiazide, quinetha- } \\
\text { zone, sildenafil, sulpiride, sumatriptan, xipamide }\end{array}$ \\
\hline- & + & dapsone \\
\hline
\end{tabular}


11. Tilles SA. Practical issues in the management of hypersensitivity reactions: sulfonamides. South Med J 2001;94:817-24.

12. Knowles S, Shapiro L, Shear NH. Should celecoxib be contraindicated in patients who are allergic to sulfonamides? Revisiting the meaning of "sulfa" allergy. Drug Saf 2001;24:239-47.

13. Strom BL, Schinnar R, Apter AJ, et al. Absence of cross-reactivity between sulfonamide antibiotics and sulfonamide nonantibiotics. N Engl J Med 2003;349:1628-35.

14. Reilly TP, Ju C. Mechanistic perspectives on sulfonamide-induced cutaneous drug reactions. Curr Opin Allergy Clin Immunol 2002;2:307-15.

15. Wood L, Martinez C. The General Practice Research Database: role in pharmacovigilance. Drug Saf 2004;27:871-81.

16. Walley T, Mantgani A. The UK General Practice Research Database. Lancet 1997;350(9084):1097-9. DOI 10.1016/S0140-6736(97)04248-7

17. Garcia Rodriguez LA, Perez Guttham S. Use of the UK General Practice Research Database for pharmacoepidemiology. Br J Clin Pharmacol 1998;45:419-25. DOI 10.1046/j.1365-2125.1998.00701.x

18. Riedl MA, Casillas AM. Adverse drug reactions: types and treatment options. Am Fam Physician 2003;68:1781-90.

19. Montastruc JL, Lapeyre-Mestre M, Bagheri H, Fooladi A. Gender differences in adverse drug reactions: analysis of spontaneous reports to a regional pharmacovigilance centre in France. Fundam Clin Pharmacol 2002;16:343-6. DOI 10.1046/j.1472-8206.2002.00100.x

20. Slatore CG, Tilles SA. Sulfonamide hypersensitivity. Immunol Allergy Clin North Am 2004;24:477-90, vii. DOI 10.1016/j.iac.2004.03.011

21. Evans RS, Lloyd JF, Stoddard GJ, Nebeker JR, Samore MH. Risk factors for adverse drug events: a 10-year analysis. Ann Pharmacother 2005; 39:1161-8. Epub 2005 May 16. DOI 10.1345/aph.1E642

22. Beyth RJ, Shorr RI. Epidemiology of adverse drug reactions in the elderly by drug class. Drugs Aging 1999;14:231-9.

23. Hajjar ER, Hanlon JT, Artz MB, et al. Adverse drug reaction risk factors in older outpatients. Am J Geriatr Pharmacother 2003;1:82-9. DOI 10.1016/S1543-5946(03)90004-3

\section{EXTRACTO}

TRASFONDO: La estructura química de los antibióticos y no-antibióticos sulfamidas pueden afectar el potencial para el desarrollo de reacciones adversas.

OBJETIVO: Determinar si diferencias químicas de varias drogas sulfamidas influencian el riesgo de eventos alérgicos.

MÉTODOS: Un estudio de caso-control fue conducido en pacientes con diabetes usando datos de la "General Practice Research Database." Los casos fueron definidos como pacientes que tuvieron una diagnosis de hipersensibilidad o reacción alérgica. La fecha del último acontecimiento alérgico fue la fecha índice. Los pacientes control fueron pareados de acuerdo a la práctica médica, tipo de diabetes, y fecha índice. El uso actual de sulfamidas fue definido como su uso en una ventana temporal de 14 días antes de la fecha índice. Las sulfamidas fueron clasificadas según la presencia u ausencia de sustitutos al N1 $\left(\mathrm{N} 1^{+} / \mathrm{N}^{-}\right)$y/o de un arylamine en la posición N4 (N4+ / N4-). Se utilizó regresión logística condicional para estimar la fuerza de la asociación y este fue expresado como proporción de probabilidad (odds ratios, OR) e intervalos de confidencia de $95 \%(95 \% \mathrm{CI})$.
RESULTADOS: Por lo general, el uso actual de sulfamidas $\mathrm{N} 1^{+} \mathrm{N} 4^{+}$estaba asociado con la ocurrencia de hipersensibilidad y reacciones alérgicas (OR ajustada 3.71, 95\% CI 1.40 y 9.81). El uso de sulfamidas $\mathrm{N1}^{+} \mathrm{N}^{-}$ y N1- $\mathrm{N}^{-}$también estaban asociados con la ocurrencia de reacciones alérgicas, pero ésta asociación no era tan fuerte: OR ajustada 2.48 (95\% CI 2.12 y 2.89$)$ y 2.07 (95\% CI 1.74 y 2.46), respectivamente. El sexo y la edad parecieron ser modificadores del efecto. No había evidencia clara para modificación del efecto por la presencia de enfermedad inmune.

CONCLUSIONES: Aunque no se encontró diferencias mayores entre los grupos, se cree que esta maniobra es una manera innovadora para evaluar reacciones adversas y clasificar exposición por medio del uso de estructuras químicas en ves de la clase terapéutica del medicamento.

Carlos da Camara

RÉSUMÉ

ÉTAT DES CONNAISSANCES: La structure chimique des antibiotiques dits sulfamidé et des autres médicaments, non antibiotiques, contenant un groupement sulfamidé pourrait affecter le potentiel pour les effets indésirables.

OBJECTIF: Évaluer si les différences dans la structure chimique des différents médicaments dits sulfamidé influencent le risque d'évènements allergiques.

MÉTHODOLOGIE: Une étude cas-témoins a été réalisée parmi des patients souffrant de diabète mellitus (DM), en utilisant les données du General Practice Research Database. Les cas ont été définis comme étant des patients ayant un diagnostic de réaction allergique ou d'hypersensibilité. La date du dernier évènement est considérée comme la date index. Les témoins ont été assortis selon la pratique, le type de diabète et la date index. L'utilisation de médicaments dits sulfamidé a été définie comme étant une utilisation dans une fenêtre de 14 jours avant la date index. Les médicaments dits sulfamidé ont été classés selon la présence ou l'absence d'un groupement N1 $\left(\mathrm{N1}^{+} /\right.$) et/ou un groupement arylamine $\left(\mathrm{N}^{+}{ }^{-}\right)$. La régression logistique conditionnelle a été utilisée pour estimer la force d'association et est exprimée en rapports de probabilités (odds ratio [OR]) et en intervalles de confiance 95\% (IC 95\%).

RÉSULTATS: Dans l'ensemble, l'utilisation des médicaments dits sulfamidé contenant les groupements N1 et N4 a été associée avec des évènements allergiques (OR ajusté 3.71, IC 95\% 1.40 à 9.81). L'utilisation de médicaments dits sulfamidé ne contenant aucun de ces 2 groupements ou seulement le groupement N1 a aussi été associée avec la survenue de réactions allergiques, mais pas avec une association aussi grande: OR ajusté 2.07, IC 95\% 1.74 à 2.46 et OR ajusté 2.48, IC 95\% 2.12 à 2.89 respectivement. Le sexe et l'âge semblent être des modificateurs de l'effet. Il n'y a pas de preuve claire d'une modification de l'effet par l'état immunitaire du patient.

CONCLUSIONS: Bien qu'aucune différence importante n'ait été notée entre les groupes, cette approche est une nouvelle façon d'examiner les effets indésirables aux médicaments en utilisant la structure chimique au lieu de la classe thérapeutique pour caractériser l'exposition.

Marie Larouche 